
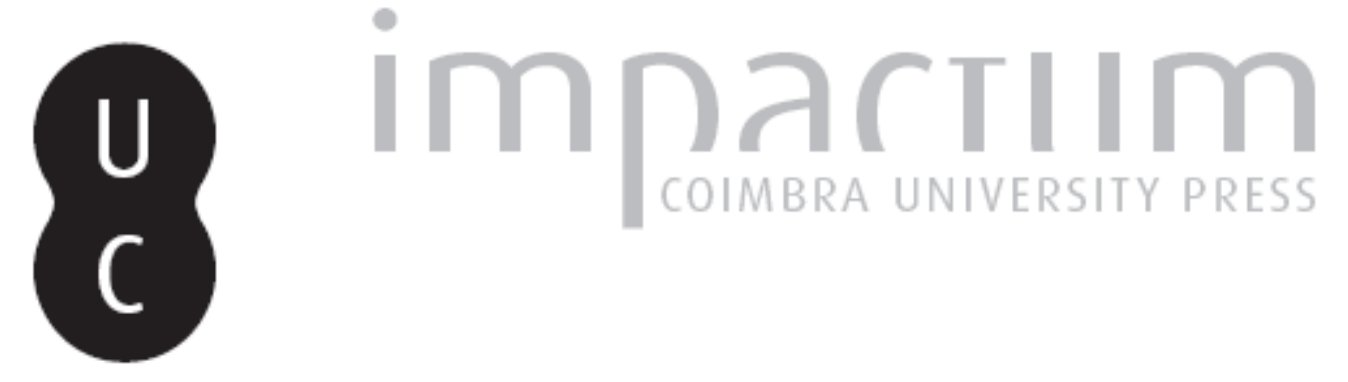

Portugal e o governo das paixões: História e Política em António Caetano do Amaral

Autor(es): $\quad$ Mota, Isabel Ferreira da

Publicado por: Imprensa da Universidade de Coimbra

URL persistente:

URI:http://hdl.handle.net/10316.2/35444

DOI:

DOI:http://dx.doi.org/10.14195/0870-4147_45_25

Accessed : $\quad$ 26-Apr-2023 11:48:01

A navegação consulta e descarregamento dos títulos inseridos nas Bibliotecas Digitais UC Digitalis, UC Pombalina e UC Impactum, pressupõem a aceitação plena e sem reservas dos Termos e Condições de Uso destas Bibliotecas Digitais, disponíveis em https://digitalis.uc.pt/pt-pt/termos.

Conforme exposto nos referidos Termos e Condições de Uso, o descarregamento de títulos de acesso restrito requer uma licença válida de autorização devendo o utilizador aceder ao(s) documento(s) a partir de um endereço de IP da instituição detentora da supramencionada licença.

Ao utilizador é apenas permitido o descarregamento para uso pessoal, pelo que o emprego do(s) título(s) descarregado(s) para outro fim, designadamente comercial, carece de autorização do respetivo autor ou editor da obra.

Na medida em que todas as obras da UC Digitalis se encontram protegidas pelo Código do Direito de Autor e Direitos Conexos e demais legislação aplicável, toda a cópia, parcial ou total, deste documento, nos casos em que é legalmente admitida, deverá conter ou fazer-se acompanhar por este aviso.

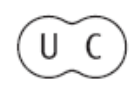




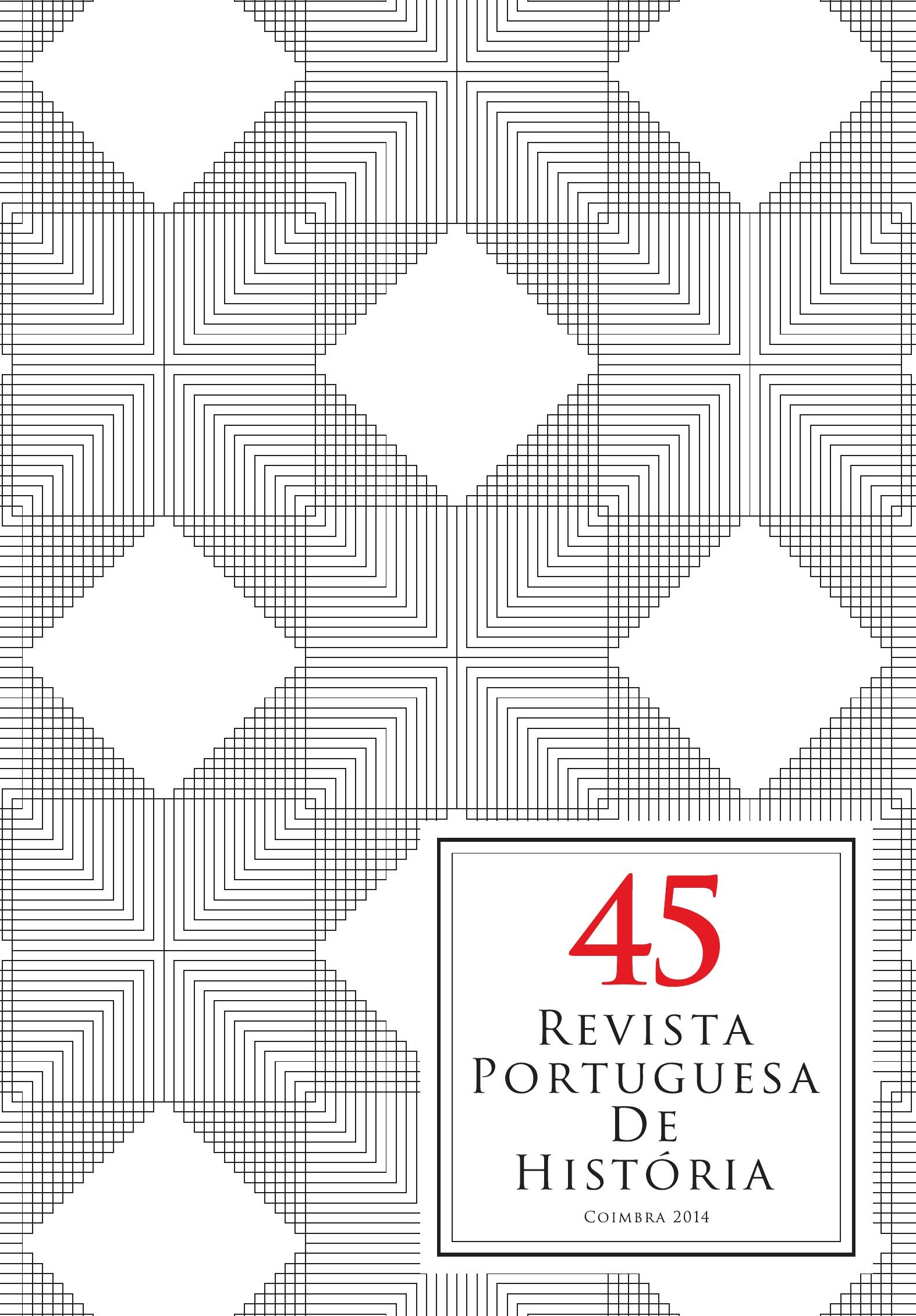




\title{
Portugal e o Governo das Paixões História e Política em António Caetano do Amaral*
}

\author{
The government of the passions. \\ History and Politics in António Caetano do Amaral
}

\author{
ISABEl FERREIRA DA MOTA \\ Faculdade de Letras da Universidade de Coimbra \\ Centro de História da Sociedade e da Cultura - FLUC \\ ifmota@fl.uc.pt
}

Resumo:

É no âmbito da Academia Real das Ciências e num período de afirmação do reformismo jus-racionalista que António Caetano do Amaral concebe o seu Projecto de uma História Civil da Monarquia Portuguesa. O seu objectivo é construir a história de tudo o que toca ao governo interior da Monarquia e, desse modo, elaborar um conhecimento útil aos Legisladores e aos Ministros que resulte num melhor governo político. A História que empreende propõe-se, por conseguinte e desde logo, como intervenção política, mas também como intervenção religiosa, ao nível da disciplina da Igreja. Como e em que sentido, é o que este artigo se propõe analisar.

\section{Palavras-chave:}

Historiografia; Política; Academia Real das Ciências; António Caetano do Amaral.

\begin{abstract}
:
António Caetano do Amaral set out his Project of a Civil History of the Portuguese Monarchy under the Royal Academy of Sciences and at a time in which jus rationalism increased its influence. His goal was to develop a history of everything concerning the inner governance of the Monarchy, and thereby to make available to Legislators and Ministers useful knowledge for enhancing the political governance. The History he envisions was thus, from the beginning, thought of as a means of political intervention, but in addition, also, as a form of religious intervention over the discipline of the church. The present paper is aimed at analyzing how and in what sense these goals were pursued by Caetano do Amaral.

Keywords:

Historiography; Politics; Royal Academy of Sciences; António Caetano do Amaral.
\end{abstract}


Na suposição de que a politica não ha de exigir dos homens huma perfeição, de que não são capazes...deve dirigir suas regras por huma sabia, e astuta combinação a interessar as suas paixões no bem da sociedade, contendo-lhes o desenfreio.

PEÑALOSA Y ZUÑIGA, A Monarquia (tradução de António Caetano do Amaral) $^{1}$

António Caetano do Amaral (aqui também designado por ACA), filho de António do Amaral, Guarda do Número da Casa da Índia, e de Joana Inácia do Nascimento, nasceu em Lisboa em Junho de 1747 e faleceu, na mesma cidade, em Janeiro de 1819. De origem familiar modesta, foi mais um caso de homem de Letras que ascendeu socialmente através do mérito, embora, apenas e tão só, tanto quanto o mérito poderia deixar ascender quando não combinado com capital familiar. Segundo Mendo Trigoso, seu par e panegirista na Academia das Ciências, o "talento e sisuda aplicação" manifestaram-se desde os mais tenros anos. De compleição física débil, modesto e tímido, muito propenso aos exercícios de piedade, iniciou os seus estudos preparatórios em humanidades após o que passou à Universidade de Coimbra. Matriculou-se na Faculdade de Cânones, em 1767, fazendo as suas conclusões em Cânones em Junho de 1771, ainda na Universidade pré-Pombalina. Entretanto os novos estatutos da Reforma Pombalina foram mandados executar e a reforma entrou em vigor na Faculdade de Cânones a partir de Outubro de 1772, trazendo consigo uma nova cadeira de "Direito natural, público e universal, e de Direito das gentes", que veiculava as posições do jusnaturalismo. António Caetano do Amaral, como os restantes alunos, foi obrigado a provar o "aproveitamento dos anos já frequentados", fazendo acto de formatura logo no primeiro ano da reforma, isto é, em 1773. Este acto de formatura foi já realizado na presença do reitor e reformador Francisco de Lemos Pereira Coutinho e segundo as orientações da reforma de Pombal enunciadas no Compêndio histórico do estado da Universidade ${ }^{2}$. Terminado o seu curso regressou a Lisboa onde se integra nas redes de sociabilidade erudita da capital (segundo Mendo Trigoso, "era acolhido, procurado e estimado por todos, em razão do seu saber, e distincto

${ }^{1}$ A Monarquia, traduzida do original castelhano de Clemente Peñalosa y Zuñiga.... por António Caetano do Amaral, Lisboa, Regia Officina Typografica, 1798, pp. 7-8.

${ }^{2}$ Compêndio histórico do estado da Universidade de Coimbra, Regia Officina Typográfica, 1771 . 
comportamento"3), isso permitiu-lhe ser escolhido para sócio supranumerário logo aquando da fundação da Academia Real das Ciências em 1780.

É, pois, com a fama de erudito e o capital cultural da sua formatura em Cânones que ACA entra na Academia. António M. Hespanha, sobre esta década em que é fundada a Academia Real das Ciências, e particularmente no que diz respeito às áreas em que se move Amaral, refere o seguinte: "na verdade, é muito claro que, a partir da década de oitenta do séc. XVIII, o reformismo jus-racionalista se afirma como cultura política dominante nos círculos que pensam, e que ocupam o novo espaço público da literatura académica, dos jornais, das academias, das repartições da nova "administração activa" reformista" ${ }^{4}$ É no âmbito deste "reformismo jus-racionalista", presente igualmente na Academia das Ciências, que ACA situará os seus estudos históricos. Que interpretação deu a este jus-racionalismo é o que tentaremos compreender.

\section{Racionalidade política e governo das paixões}

Logo no primeiro ano de existência da Academia, em 19 de Julho de 1780, apresentou Amaral em sessão académica o Projecto de huma História civil da Monarchia Portuguesa ${ }^{5}$. Aqui, e também no Plano da História Civil apresentado à Academia na Assembleia de 15 de Novembro de $1780^{6}$, expõe o historiador a sua concepção de história, os seus objectivos e o seu método. Nas suas palavras, pretende "empreender....huma História, que tenha por objecto

\footnotetext{
${ }^{3}$ Sebastião Francisco de Mendo Trigoso, "Noticia Historica da vida e escritos de Antonio Caetano do Amaral" in Historia e Memorias da Academia Real das Sciencias de Lisboa, Tomo VIII, Parte II, Lisboa, Typografia da Academia,1823, pp. 47-57 (2. edição em Memoria V, Para a história da legislação e costumes de Portugal, edição de M. Lopes de Almeida e César Pegado, Porto, L. Civilização, 1945, pp. 53-63).

${ }^{4}$ António Manuel Hespanha, Guiando a mão invisível. Direitos, Estado e Lei no Liberalismo Monárquico Português, Coimbra, Almedina, 2004, p. 45. Sobre ACA ver Luís A. de Oliveira Ramos, "António Caetano do Amaral e a História Portuguesa" in Revista da Universidade de Coimbra, vol. 30, Coimbra, 1984, pp. 497-511; Luís Reis Torgal, “Antes de Herculano...” in Luís Reis Torgal, José Amado Mendes e Fernando Catroga, História da História em Portugal (séculos XIX e XX), Lisboa, Círculo de Leitores, 1996, pp. 19-37; Joaquim Veríssimo Serrão, A Historiografia Portuguesa. Doutrina e Crítica, vol. III, Lisboa, Verbo, 1972-1974, pp. $227-$ -230; Beatriz Amélia Sousa Oliveira, Conceitos de História em António Caetano do Amaral, Coimbra, 1968 (tese de Licenciatura).

${ }^{5}$ Apresentado na Academia das Sciencias, na Assembleia de 19 de Julho de 1780 in Luís A. de Oliveira Ramos, ob. cit., pp. 506-508.

${ }^{6}$ Idem, pp. 508-511.
} 
tudo o que toca ao governo interior da Monarchia Portugueza.... não digo huma simples Historia do Direito Portuguêz, cingida às nossas leis escritas: quem não sabe a grande parte, que na vida Civil tem outras leis não escritas, que naturalmente manão do génio dos Povos, quero dizer, os costumes, e os uzos" " . O seu objectivo não é portanto edificar história guerreira, nem política, tão pouco uma história eclesiástica nem uma história topográfica ou natural, mas antes "uma obra, que deve dar a conhecer o sistema da Legislação e de toda a direcção domestica da Monarchia", isto é, uma História do "sistema" da "Sociedade Civil" (Plano...). Esta História será, segundo Caetano do Amaral, sumamente útil porque aí verá "o Legislador bem às claras o génio, e indole do seu Povo, as paixões que o tem dominado; os efeitos, que nelle tem produsido este, ou aquelle género de Legislação... a ocasião, que deo cauza a muitas leis" ". Só nesta história igualmente, diz, o Jurisconsulto "achará.... a verdadeira arte da interpretação legal", e só nela os ministros encontrarão os meios que o País tem dentro de si para crescer em opulência e em policia. Para uma melhor organização política, o conhecimento do espírito ou natureza dos povos é, pois, fundamental. É a ideia de que nada poderá ajudar mais aos destinos de um Estado do que o conhecimento das suas qualidades específicas: o seu povo, a sua história, os seus recursos, as suas paixões, os seus costumes. A história que ACA se propõe fazer deverá, portanto, contribuir, no limite, para uma maior racionalidade governativa no seu país, e isso decorrerá sobretudo do melhor conhecimento da natureza do povo português, porque o bom governo é também o governo das paixões. A história é pois, em última análise, intervenção política, mas para ACA ela propõe-se também como intervenção religiosa, ao confrontar a disciplina da Igreja do seu tempo com as vidas e obras de S. Frutuoso e de S. Martinho - objecto de duas publicações suas adiante referidas -, e por aí com a Disciplina Eclesiástica "dos felizes tempos da primitiva Igreja".

Os consócios aplaudiram o Projecto, mas permaneceram cépticos quanto à viabilidade de execução de um tão ambicioso plano. Ele nada tinha de diferente, porém, do próprio projecto da Academia, expresso pelo Abade Correia da Serra, no "Discurso Preliminar" da edição das Memorias Económicas da Academia Real das Ciências (Tomo I, 1789). Aí diz Correia da Serra, secretário da instituição e uma das suas principais figuras, que o fim último da Academia é adiantar a pública prosperidade, para a qual a história concorre de modo determinante: "o conhecimento do que a nação é e do que pode ser, pelo

\footnotetext{
${ }^{7}$ Projecto de uma historia civil ..., p. 507.

${ }^{8}$ Projecto... p. 507.
} 
que já tem sido, é dos mais úteis para a sua felicidade, e só pode esperar-se dos esforços unidos de um corpo tal, como a Academia"9. E porquê? Segundo Correia da Serra porque a história de cada povo corresponde a "séries de acções, motivadas por modos de ver, de discorrer, e de desejar". A história da nação mostra portanto "o modo de ser", ou, nas palavras de ACA, o "génio" de um povo. Na Colecção de Livros Inéditos publicados por ordem da Academia Real, o secretário da Academia reitera a mesma opinião, que é também a de ACA: para as leis que nos governam, a forma da administração pública e os usos que seguimos, só na história poderemos encontrar "a explicação da sua natureza"10. Resumindo, "hé preciso em fim, conclui ACA, que nós mesmos nos conheçamos". Racionalismo ou pré-romantismo, nesta visão da história e da política? Talvez só época de transição, o que significa justamente múltiplas combinações entre passado e futuro, isto é, temporalidades múltiplas.

Em 1798, Caetano do Amaral, através da tradução que faz do livro A Monarquia, do autor espanhol Clemente Peñalosa y Zuñiga, especifica as suas concepções políticas, nomeadamente fundamenta a sua teoria das paixões no que toca ao governo da Monarquia.

Como se sabe, a tradução é, muito frequentemente, senão maioritariamente, uma apropriação, e este é o caso da tradução de ACA. Numa nova forma de autoria e de autoridade do tradutor, Amaral dedica a "sua obra" ao príncipe regente, D. João, futuro D. João VI. Nesta interactividade que é o gesto de traduzir, ACA e Zuñiga explicam que "he tão difícil dar o ser a huma sociedade perfeita de homens, como facil o inventalla" ${ }^{11}$, caso de Bacon, Campanella ou Fenelon. A ciência do governo supõe, portanto, necessariamente, "uma ordem exacta de cousas" em que os legisladores não devem empenhar-se porque é melhor, visto que o melhor nem sempre é possível porque "sempre será combatido por paixões dominantes, e poderosas" 12 . Ora, não há forma de governo que possa destruir as paixões nem dos que mandam nem dos que obedecem. Deste modo, na suposição de que a política não pode exigir dos homens uma perfeição de que não são capazes, almas sempre prontas a abusar das Leis, então a política "deve dirigir suas regras por huma sabia, e astuta combinação a interessar as suas paixões no bem da sociedade, contendo-lhes

\footnotetext{
${ }^{9}$ Memorias..., tomo I, pp. 10 e 11.

${ }^{10}$ Cf. "Discurso Preliminar" in Colecção...

${ }^{11}$ Ob. cit., p. 6

${ }^{12}$ Idem, p. 7
} 
o desenfreio"13. São as paixões do homem "instrumentos úteis" na mão de um Administrador prudente cuja acção seja suave e poderosa ${ }^{14}$.

A racionalidade política (ou pragmatismo político) é, pois, governar as paixões, não acabar com elas; porque pretender acabar com as paixões do homem é "delírio". O que convém é dirigi-las ou então "quebrantallas", quando se não podem satisfazer sem detrimento da "ordem moral". É justamente aqui que o governo monárquico se perfila como a forma mais "temperada" de encaminhar as paixões para o bem, manejando-as "com mais rectidão" em interesse do Estado. A Monarquia que ambos defendem é uma monarquia "absoluta e moderada". Poder absoluto (embora não arbitrário), porque a posse e pleno exercício do poder, "que em todo o governo denota quem he o Soberano, põe nas mãos do Monarca absoluto huma autoridade independente" ${ }^{15}$. Todas as máximas políticas no livro A Monarquia, da autoria de Zuñiga, são demonstradas com exemplos retirados à História; nas Memorias de Caetano do Amaral, o estudo rigoroso da História resulta em máximas políticas. E elas são as mesmas. De modo que, na Dedicatória, ao apresentar este livro como "retrato" do soberano a quem é dedicado, D. João (príncipe regente), o tradutor diz ao Príncipe aquilo que ele é e que deve ser.

\section{Objecto e método: "mostrando a ligação das coizas"}

Na mesma sessão académica em que apresentou o seu Projecto de huma Historia Civil da Monarchia Portuguesa prometeu Amaral, caso o Projecto fosse aprovado, apresentar em sessão imediata o Plano que pretendia seguir. Será, diz, uma História Civil, mas não se pode dispensar de dar em cada época uma ideia do estado da nação pelo que toca à religião e às forças tanto de milícia, como de comércio, que, "por serem os nervos do Estado, são assunto de muitas Leis do Direito Publico". Além de cultor da história jurídica, ACA será portanto, como reconhece Alexandre Herculano, e no que toca à Idade Média, o fundador da história social do povo português ${ }^{16}$. O "Plano"

${ }^{13}$ Idem, p. 8.

${ }^{14}$ Recorde-se Descartes, na carta à princesa Elisabeth, 1.09.1645, "E porque as [paixões] do corpo são as menores, pode dizer-se em geral que, sem elas há meios para alcançar a felicidade. Contudo, de modo nenhum sou de opinião que se deva inteiramente desprezá-las, nem que devamos isentar-nos de ter paixões; basta torná-las submissas à razão e, uma vez assim aprisionadas, são por vezes tanto mais úteis quanto mais elas tendem para o excesso".

${ }^{15}$ Idem, p. 49.

${ }^{16}$ Ver Alexandre Herculano, Opusculos. Controversias e Estudos Historicos, t. V, Casa da Viuva Bertrand \& C. ${ }^{a}$, Lisboa, 1886, pp. 106 e 202. 
de Amaral divide a sua obra em épocas e como a História que faz é sobretudo a da Monarquia, as primeiras épocas serão como que uma "Introdução" que compreenderá 4 fases: a Lusitânia pré-romana, o período romano, o período bárbaro e a época árabe. No tempo do casamento do Conde Dom Henrique e princípio das suas conquistas começará finalmente a História e esta primeira parte da História estender-se-á até ao final do reinado de D. Fernando; nova época irá até ao reinado de D. Sebastião; a 3. época começará no período filipino e terminará no tempo coevo do autor. O Plano da História Civil apresenta ainda o método a utilizar na obra em execução. Quanto ao método, diz, não fará uma "história positiva", acumulando documentos, porque nesse caso "não comporia Historia; acarretaria provas para ella", mas também, no extremo oposto, não fará "hum Discurso abstracto". E conclui : "ameaçado destes dois extremos, julguei que seguiria hum meio racionável, se levando hum discurso seguido, mas cingido sempre às memórias históricas, que o produzem, fosse com ele mostrando aos Leitores a ligação das coizas”. Por conseguinte, uma história racional e explicativa, carregada de referências a documentos originais, mas em notas, onde os leitores possam compreender a natureza das coisas ${ }^{17}$. Se usou de "critica judiciosa" quanto às fontes, se procurou os meios para "entrar no espirito dos tempos remotos, e não os interpretar pelas ideias presentes", se falou "a verdade" - os confrades o julgariam a seu tempo e os leitores fariam "os seus juízos". Submeter os próprios trabalhos à crítica dos Pares e contribuir com eles para a "verdade", num ideal de obra colectiva, foi um dos contributos maiores destas Academias modernas.

Paulo Merêa ${ }^{18}$ não hesitou em elogiar a obra de Amaral, apelidando-a de "profundamente original", "preciosamente documentada", sustentada pela "mais segura erudição" e pelos "privilegiados dotes críticos" do autor. Ainda segundo Merêa, ACA encarna as novas tendências da história jurídica na transição para o século XIX. Tal como Merêa, muitos outros historiadores não pouparam elogios à obra de Amaral, como é o caso, já referido, de Alexandre Herculano, ou ainda o de Fortunato de Almeida, Inocêncio Francisco da Silva, Gama Barros ou Sánchez-Albornoz.

A morte aos 72 anos não o deixou concluir o seu "Plano". A obra terminou na memória V - 1. ${ }^{a}$ época da Monarquia Portugueza, desde o Conde

${ }^{17}$ Cf. Plano..., p. 510.

18 "Súmula Histórica da História do Direito Português" in Boletim da Faculdade de Direito da Universidade de Coimbra, Coimbra, Ano 5 (1918-1919), pp. 216-228 e Ano 6 (1920-1921), pp. 95-105. 
D. Henrique até o fim do reinado d' El Rei D. Fernando -, ficando por elaborar as duas últimas "Épocas". A Academia, no projecto da qual a obra de Amaral se integrava, premiou o seu autor imediatamente aquando da apresentação da primeira Memória: foi nomeado sócio efectivo na Classe de Literatura, e foi nesta condição que, em 1786, lhe coube abrir, com uma oração, a sessão pública celebrada no Real Palácio das Necessidades. Era a consagração da obra e do autor pela Academia. A Memória II foi lida em 1791 e, tal como as outras, inserida nas Memorias de Literatura Portugueza, publicadas pela Academia.

Mas estes eruditos precisavam de meios de subsistência que simultaneamente lhes permitissem dedicar-se exclusivamente aos seus estudos. E assim acontecia também com António Caetano do Amaral: detinha o módico rendimento de um Benefício na Igreja de S. Lourenço e, justamente em 1791, foi nomeado Deputado do Santo Officio da Inquisição de Lisboa. A Inquisição era, porém, já uma sombra de si mesma. Nestes anos 90, a reforma pombalina fazia-se já sentir plenamente nas mudanças da Inquisição, ela estava sobretudo ao serviço do estado e as penas eram quase exclusivamente espirituais. As redes de influência que atingiam pessoas e instituições permitiam, no entanto, que os cargos numa instituição servissem de segurança económica para o trabalho intelectual noutra instituição. Passados menos de 8 anos, nova promoção: toma posse do lugar de Cónego da Catedral de Évora. Promoção proporcionada certamente pela sua posição como Deputado da Inquisição de Lisboa, mas também correspondente ao sucesso dos seus estudos e ao prestígio e influência da Academia. Não queria todavia deixar a capital, por isso renunciou a este Benefício Eclesiástico em 1806, reservando para si uma pequena parte da pensão com que subsistiu até ser nomeado, em 1816, Inquisidor da Inquisição de Lisboa.

Entretanto, também na Academia Caetano do Amaral prosseguia o seu “cursus honorum". Saindo a público, em 1796, a Memória III, foi nos princípios de 1797 designado para secretariar interinamente a Academia Real durante os impedimentos de Correia da Serra e, quando Garção Stockler substituiu Correia da Serra na função de secretário da Academia, Amaral foi reeleito Vice-secretário por repetidos triénios. Em 1818 é nomeado Director da Classe de Literatura.

\section{História e reformismo jus-racionalista}

Analisemos agora, de forma mais minuciosa, a obra que entretanto produzia. No Prólogo do Tomo I das Memorias de Literatura Portugueza explicita- 
-se que são a Língua e a História Portuguesas os dois objectos que constituem o que a Academia quis entender por Literatura Portuguesa. Assim, logo neste primeiro Tomo das Memorias de Literatura, publica-se a Memoria I dedicada ao "Estado da Lusitania até ao tempo em que foi reduzida a Provincia Romana" 19 . Com todas as cautelas e reduzido à escassez de fontes, o autor rejeita a "gloria vã, que se busca em antiguidades mentirosas" e acentua, nos Lusitanos, a simplicidade da legislação - "leis raras e costumes singelos" -, a "austera sobriedade" e o "amor da liberdade".

A Memória II é dedicada ao estudo do "Estado Civil da Lusitania no tempo em que esteve sujeita aos romanos" ${ }^{20}$. Ao imenso e sólido aparato crítico, baseado sobretudo em autores clássicos e inscrições romanas, não corresponde igual fôlego narrativo, sempre travado pela concepção rígida dos propósitos iniciais do estrito "Estado Civil". O domínio que detém das fontes escritas permitir-lhe-ia o explorar de múltiplos caminhos, mas isso ultrapassava o limite do seu projecto a que procurou manter-se sempre fiel. Fica o riquíssimo catálogo das fontes acompanhado de indicações seguras para a sua exploração. A conclusão da Memoria II é que neste "estado de sujeição Civil debalde buscaríamos legislação propria dos Lusitanos, ou formada por elles mesmos, ou emanada de Roma" (p. 344). Deste modo, a decadência é não só dos Romanos mas também dos Lusitanos: "o que também não pode deixar de se distinguir he hirem os Lusitanos pouco a pouco tornando-se Romanos; costumes, gosto, usos, génio, tudo se vai amoldando aos dos Conquistadores" (p. 348). O epílogo é moralizador: "esta he a triste scena, que a Lusitania nos apresenta pelo espaço de quatro séculos, em que faz parte do Imperio Romano: sem forças, nem virtudes de guerra, que lhes dem gloria ...; sem systema de governo nem legislação propria, que lhes dê caracter certo, e particular; mas huma como materia inerte... sem se lhe infundir jamais espirito, que a anime" (p. 353).

Na Memória III, "Sobre o Estado Civil da Lusitania, desde a entrada dos Povos do Norte até á dos Arabes" ${ }^{21}$, e a propósito da forma de governo dos Povos do Norte, que aponta como um governo monárquico hereditá-

${ }^{19}$ António Caetano do Amaral, "Memorias sobre a fórma do Governo, e costumes dos Póvos que habitarão o terreno Lusitano, desde os primeiros tempos conhecidos, até ao estabelecimento da Monarquia Portugueza. Memoria I, Estado da Lusitania até ao tempo em que foi reduzida a Provincia Romana" in Memorias de Litteratura Portugueza, Tomo I, Lisboa, Academia Real das Sciencias de Lisboa, 1792, pp. 16-30.

${ }^{20}$ Idem, Tomo II, pp. 313-353.

${ }^{21}$ Idem, Tomo VI, pp. 127-437. 
rio, afirma Amaral: "e este Paiz, que a Providencia destinára para assento de Monarquia... sempre acha governo de hum só" (p. 137). Afirmação peremptória e não despicienda em tempo de Revolução Francesa. Fazendo-se agora os Godos únicos senhores da Lusitânia, eles tomaram, conforme as distintas regiões por que se espalharam, os costumes que os "climas", as "comunicações", as "necessidades", "e outros diferentes adjuntos" lhe deram e o mesmo aconteceu na Lusitânia. Amaral explica que não é partidário dos que dão um poderosíssimo influxo ao clima sobre os costumes dos povos, mas concorda que não se pode negar que algum tenha. Sabemos que conhece bem o Espírito das Leis, de Montesquieu, porque cita esta obra variadas vezes, umas para concordar outras para discordar. É possível que Montesquieu tenha sido em parte fonte de inspiração para ACA, sobretudo enquanto historiador. Apesar de o Espírito das Leis ter causado muitas polémicas e ter sido um livro controverso, Montesquieu estava no entanto presente nas livrarias de Lisboa, nomeadamente dos conventos. O clima é, para Montesquieu tal como para ACA, apenas um de muitos factores que contribuem para o "espírito geral" de uma sociedade. Sendo o clima uma causa física, os outros factores (entre os quais os mais importantes são as leis, a religião e as máximas de governo) eram de natureza não física. É dever do legislador contrabalançar a influência do clima, diz Montesquieu, visto que esta influência não é insuperável, salvo em sociedades primitivas. Na verdade, para Caetano do Amaral tanto é a legislação que se acomoda ao "génio do povo", como pode também ser a legislação a contribuir para configurar o "carácter" desse povo. A Memoria III aprofunda, num constante recurso às fontes que domina superiormente, $\mathrm{o}$ estudo do Código Visigótico e da forma do Governo neste novo Estado Civil. E aqui surge, de imediato, uma análise importante: "he preciso reflectir em quem he o Legislador; quero dizer, em quem tem aqui o poder Soberano; que espécie de Governo, e Estado Civil he este, que de novo nasce na Lusitania" (p. 156). E ACA continua: "desde que aquí aparecem Wisigodos, aparecem presididos de hum Rei”, cuja sucessão passava normalmente de pai a filho ou de irmão a irmão, embora raramente fosse pacífica. Com as "Leis Civis" e para acautelar as rebeliões e usurpações do trono, os Reis Godos são eleitos com os votos das "Ordens distinctas do estado" e conduzidos ao trono com a aprovação geral, mas não ignoram que, uma vez eleitos, de Deus recebem imediatamente o poder soberano. É pois, conclui ACA, uma Monarquia modificada, mas essa partilha que o monarca dá nos direitos da Soberania não é igualmente comunicada às diversas Ordens (pp. 158-160). As circunstâncias fazem com que o maior peso resida nos "Prelados Eclesiásticos", até porque os Bárbaros foram criados, mesmo no paganismo, na subordinação e 
respeito aos Ministros da Religião. No entanto, apesar de ser muito grande a parte que os Eclesiásticos tinham no governo visigótico, também os Nobres tinham alguma (maior, diz ACA, do que porventura lhes caberia em pura Monarquia).

Quanto à legislação dos Visigodos, em vez de ser ela - estudando e dirigindo todas as causas físicas e morais que possam influir nos costumes de um Povo - a formar o carácter social deste Povo, é, pelo contrário, a "torrente impetuosa dos costumes" que arrasta a Legislação e a faz variar segundo o capricho das paixões, ou a ocorrência dos sucessos (p. 203). Contudo, e entrando já na análise das Ordenações Visigóticas, não são ignorados dos visigodos os ofícios recíprocos de soberano e de vassalos: jura o rei, na entronização, cumprir as obrigações que tem para com os súbditos, juram estes cumprir as suas para com o Rei - "Não desconheceram estes Barbaros, que o Principe o não he para si, mas para o Pôvo; que com este forma hum corpo, de que he Cabeça, e deve por tanto procurar a conservação dos súbditos como a de seus próprios membros: nem póde ter por commodo, ou por felicidade senão a que lhe for comum com elles: que he o ministro da autoridade de Deus, para fazer reinar a justiça, e a piedade" (pp. 206-207). Caetano do Amaral conhece bem o modelo tradicional que concebe a sociedade como "corpo" dotado de um destino metafísico, modelo que certamente estudou em doutrinas políticas de juristas e teólogos sobretudo do fim da Idade Média e início da Moderna. Como veremos, conhece igualmente bem o outro paradigma político da época moderna, o jus-racionalista.

A história que este autor faz não é, de modo nenhum, uma história neutra; ele afirma continuamente posições e princípios. É claramente uma história empenhada, moralmente, juridicamente e politicamente. A redacção definitiva desta Memória III deve ter sido prosseguida em paralelo com os estudos para outras duas obras maiores de Amaral: Vida e Opusculos de S. Martinho Bracarense $^{22}$ e Vida e Regras Religiosas de S. Fructuoso Bracarense ${ }^{23}$. Obras que realizou por encomenda do seu grande amigo, D. Fr. Caetano Brandão. O historiador e o Bispo do Pará, posteriormente Arcebispo de Braga, partilhavam as mesmas ideias sobre a necessidade de "avivar no espírito do Clero as preciosas lembranças da antiga Disciplina”. São portanto mais dois livros com intenções claras de intervenção na sociedade e na Igreja coevas, em prol de uma monarquia pura e de uma Igreja austera.

\footnotetext{
${ }^{22}$ Lisboa, Typografia da Academia Real das Ciências, 1803.

${ }^{23}$ Lisboa, Impressão Regia, 1805
} 
A Memoria V, "I. '. Epoca da Monarchia Portugueza, desde o Conde D. Henrique até o fim do reinado d' El Rei D. Fernando" ${ }^{24}$, é finalmente a entrada no verdadeiro objectivo de Amaral - "a fundação da Monarchia Portugueza”. Segundo as suas palavras, é aqui que começa verdadeiramente o corpo da Obra. Esta primeira época, durante a qual a monarquia portuguesa se manteve nos limites do continente europeu, tem por baliza final o reinado de D. Fernando. Por entre as dificuldades de um reino formado à força de conquista, "vai brotando, e pulando a planta da primitiva Legislação Portugueza, Legislação amoldada à índole de homens de guerra". Pondo-se termo à conquista, nascem novas preocupações com a "sua cultura, riqueza, e civilização; e em consequência novos objectos de Ordenações, e providencias". A primeira questão que se põe é a independência e separação do novo Estado logo com o Conde D. Henrique. Velhas lutas historiográficas o disputam, mas só as bem documentadas garantem a vitória, por isso refere o contributo decisivo de alguns colegas da Academia das Ciências, particularmente João Pedro Ribeiro. Inumeráveis documentos que se encontravam no Cartório da Academia Real das Ciências, copiados dos seus originais pelos académicos João Pedro Ribeiro, Fr. Joaquim de Santa Rosa de Viterbo e Joaquim de Santo Agostinho, servirão de base à História de Caetano do Amaral, em mais uma demonstração do trabalho colectivo que caracteriza estas Academias do séc. XVIII.

Portugal nasce, portanto, logo com o Conde D. Henrique, como Reino independente. Quanto à concessão ou confirmação do Reino pelo Papa, o autor não deixa dúvidas, é ideia totalmente errada que só pode vir da ignorância acerca dos justos limites do poder espiritual, único próprio da Igreja. A inspecção dos papas sobre o temporal dos Reinos é tão claramente irregular "que não podia deixar de ferir os olhos da razão natural" (p. 30), levando a respostas fortes e justas por parte dos Reis, nomeadamente a de D. Afonso IV sobre o provimento da Mitra do Porto. Afirmação peremptória que insere ACA na defesa regalista da separação das esferas de jurisdição papal e régia. Junta-se assim a nomes como António Pereira de Figueiredo e encontra-se, também por este lado, com o filojansenismo. Estas posições tomadas entre as controvérsias e polémicas em torno dos principais temas políticos do tempo são posições historiográficas e também religiosas, mas são sobretudo profundamente políticas.

Passa em seguida o autor a um outro ponto fundamental: o conhecimento da Constituição e forma do governo do Reino. E aqui é, mais uma vez, peremp-

${ }^{24}$ Idem, Tomo VI, Parte II, 1820 e Tomo VII, 1821. Cita-se pela edição de 1945, organizada por M. Lopes de Almeida e César Pegado, Porto, Livraria Civilização. 
tório: foi, desde sempre, "Monarquia pura" e hereditária, aliás, diz, "como o resto da raça Gotica". Já na Memória anterior se tinha visto "o mando de hum só Chefe", e, prossegue, "se vêm contemplados nos casos graves as diversas Ordens do Estado; mas só para assegurar o acerto das Ordenações, e não para influir nestas com voto decisivo" (p. 32). As Cortes de Lamego confirmam com Lei escrita a sucessão hereditária do trono, que já estava estabelecida desde o Conde D. Henrique. Segundo ACA, e na mesma linha da Academia Real da História 25 (continuava segredo de Estado), "he impróprio, e inútil a todo o Portuguez entrar na averiguação da veracidade de hum monumento, cujo conteudo está autenticamente recebido como a nossa Lei Fundamental" (p. 32).

Igualmente, diz ACA, se oferece à primeira vista a forma de Governo como puramente monárquico, isto é, as Cortes " não tinham natureza diferente da de qualquer Junta menos solene, em que os Reis ouviam os Bispos e Grandes da Corte... ninguem diria que estas secretas consultas... denotavam partilha no direito de legislar entre o Soberano, e as pessoas ouvidas, ou consultadas". Pois o mesmo se passa com as cortes, são pura "consulta". A soberania é exclusivamente do Rei. E, a propósito, vai citando em nota a Dedução Cronológica e Analítica, João Pedro Ribeiro e Pascoal José de Melo Freire. De facto, em todos estes aspectos, ACA apresenta-se em total concordância não só com os Estatutos Pombalinos da Universidade de Coimbra e a nova cadeira de Direito Natural, Público e Universal, como e sobretudo com Pascoal José de Melo Freire, com quem a coincidência de posições e pontos de vista é muito significativa. No domínio do pensamento político-religioso, a posição do autor é também clara quanto a outro ponto forte e polémico do seu tempo (posição que vai a par da de A. Pereira de Figueiredo), a questão dos bens materiais da Igreja: "o Soberano conserva hum eminente dominio em todos os bens dos seus Reinos para delles poder dispôr nas necessidades publicas" (pp. 62 e 63), tanto mais, diz, que muitos dos mesmos bens tinham sido "liberalizados" pelos próprios ou anteriores monarcas. As referências são amiúde à demasiada opulência e "exempção" dos eclesiásticos naqueles tempos, confundidos que eram, pela ignorância, os limites da jurisdição eclesiástica e secular. Assim, não foram poucos os bispos e papas que consumiram os dias do seu episcopado a procurar defender bens e direitos temporais, quando os deviam empregar "na santificação do seu rebanho, e edificação da Igreja" (p. 101). Enumera em seguida casos em que se verificam "pretenções exorbitantes dos eclesiásticos" (p. 106), bem como casos em que o Papa recorre a

${ }^{25}$ Ver Isabel Ferreira da Mota, A Academia Real da História. Os intelectuais, o poder cultural e o poder monárquico no séc. XVIII, Coimbra, Minerva, 2003, pp. 72-73. 
"remedios não só extremos, mas muito além do seu legitimo poder" (p. 103). Penaliza o autor o facto de que o poder régio não tenha sido sempre firme a "sustentar os direitos da Coroa e utilidade dos povos", mostrando-se nesses tempos por vezes vacilante, o que ACA condena. Os bons princípios da defesa dos direitos da Coroa eram "relâmpagos da luz natural", embora infelizmente não sustentados por "hum systema fixo". O mesmo se passa, na opinião de ACA, com a segunda ordem, isto é, a Nobreza. Sobretudo devido à guerra dos primeiros tempos e porque precisavam dos nobres, os Soberanos cederam-lhe muito dos seus direitos, mas, firmando-se no trono com menos dependência, os nossos reis "começárão a sentir melhor o prejuízo, que da ampliação, e extensão das Honras resultava aos direitos da sua Soberania" (p. 144). Um dos maiores privilégios que se podiam conceder a vassalos, senão o maior, era a "jurisdição cível e crime" em suas Terras, e o provimento de Ministros que nelas administrassem justiça. Mas não podia, assevera ACA, durar muito sem reforma "tão grande demasia em alhear direitos da Coroa"; o caminho dos Soberanos era só um, e por isso publicou D. Fernando a Lei restritiva e modificativa destas doações, lei que foi depois incorporada na Ordenação Afonsina. Por último, os Monarcas eram soberanos também do povo e, sendo que "a principal causa da quietação dos povos, e conservação dos vassalos he a guarda dos foros, e exempções deles", a cada Comarca e a cada Concelho concediam os Reis privilégios "à proporção do seu merecimento".

Em suma, a procura da racionalidade política e a defesa do bem público permitiam, na 1. ${ }^{a}$ época da Monarquia como nos finais do séc. XVIII, que o rei agisse em nome da sua soberania, conceito de soberania que para ACA era muito pouco ou mesmo nada limitativo do poder real. ACA fornece assim a base histórica da teoria política que "dava ao rei mais ampla margem de manobra para levar a cabo reformas", fossem sociais, religiosas e/ou políticas, na transição do sec. XVIII para o séc. XIX; nomeadamente, suportava as ideias de subordinação da Igreja ao Estado ou de um certo anti-feudalismo ${ }^{26}$. Esta posição histórica, jurídica e política, ao ser publicada nas Memórias da Academia, era, não o esqueçamos, legitimada pela própria Academia. O que não impedia que dentro da instituição houvesse visões diferentes e discordantes. Porém, neste período de transição, o reformismo jus-racionalista afirma-se, segundo A. Hespanha, como "cultura política dominante". ACA não deixou de o afirmar e sustentar historicamente.

${ }^{26}$ Cf. A. Hespanha, ob. cit., pp. 42-43. 


\section{História e (filo)jansenismo: um bispo e um historiador no final do Antigo Regime}

"Meu Bom, e especialíssimo Amigo", assim inicia Fr. Caetano Brandão, Bispo do Pará, uma carta de 20 de Março de 1784, dirigida a António Caetano do Amaral. Existia, de facto e como já referimos, entre o bispo e o historiador uma amizade atenta, sempre presente, e uma grande cumplicidade espiritual e ideológica. Nas cartas particulares de Caetano Brandão para ACA que se encontram na Biblioteca Pública de Évora ${ }^{27}$, além dos protestos de amizade e das citações de Santo Agostinho, encontram-se também as confidências e desabafos sobre as dificuldades agudas que sente no exercício do seu cargo no Pará. Exortam-se um ao outro no cumprimento do serviço de Deus, queixando-se o bispo "que o não tenho eu ao meu lado para ambos juntos fazermos guerra ao vício que nestes paizes reina com o maior despotismo! Mas faço o que posso.... faço-lhes vêr a beleza e santidade das praticas da Igreja nos seus bons séculos, e como se acha tudo desfigurado presentemente" 28 . Preocupa-o deixar obra bem feita, no Hospital feito de novo e no melhoramento do Seminário e, de caminho, encomenda ao amigo zele na Corte pelos seus interesses na fundação de um hospital. O melhoramento do Seminário é uma acção que reputa essencial para que a sua diocese disponha de um clero exemplar e instruído. Quanto ao Hospital para os pobres, ele agrada à Rainha, diz, disso o tem informado, por várias vezes, Martinho de Melo e Castro, secretário de Estado da Marinha e Ultramar. Sobre o governo de D. Maria I e a necessidade de reformas, embora saiam leis bem trabalhadas "com muita Luz e solidez", ainda assim pensa que "isto vai devagar e como a medo: quem dera hum Imperador; só este Principe corta a raiz". ${ }^{29}$

Firme no socorro corporal e espiritual da sua Igreja, citando sempre Santo Agostinho (a sua referência de longe mais frequente), mas suspirando pelo regresso ao "Cantinho da (sua) Cella". Em meio agreste e estranho, a doença atinge-o e diminui-lhe as forças físicas, pede por isso ao amigo orações a Deus, para que a resistência espiritual e o bom governo, com virtude e ciência, não vacilem. Pede-lhe também que dê lembranças aos amigos e agradece-lhe, em Março de 1785, o "bom Livro" que ACA lhe enviou; diz que já tinha visto a matéria por Febrónio, Bossuet e outros, "mas gosto sumamente deste A.". Embora sem sabermos quem é o autor, sabemos, no entanto, que Febrónio "é

\footnotetext{
${ }^{27}$ Biblioteca Pública de Évora, Cod. CX/1-10.

${ }^{28}$ Idem, Carta do Pará, de 30 de Março de 1785.

${ }^{29}$ Idem, Pará, 18 de Janeiro de 1787.
} 
o pontífice máximo do regalismo na Europa", na sua "polémica contundente e directa com o primado político, disciplinar e dogmático do papa na Igreja católica" ${ }^{30}$, ao pôr o episcopalismo em primeiro plano como alternativa ao papalismo.

É baseado nestas cartas pessoais e em outras que adquiriu, bem como em Ofícios e Pastorais, que António Caetano do Amaral compõe, pouco depois da morte do seu amigo, a sua obra Memorias para a Historia da Vida do Veneravel Arcebispo de Braga D. Fr. Caetano Brandão. ${ }^{31}$ Aí acentua o pensamento comum a ambos, evidenciando-se a espiritualidade austera, o rigor moral, a vontade de reforma da Igreja, a presença contínua dos ensinamentos de Santo Agostinho e até as tendências regalistas. Posições que em tudo aproximam Fr. Caetano Brandão e António Caetano do Amaral da corrente jansenista. Até mesmo a ideia de "graça" (tão cara ao jansenismo) e a problemática do "mysterio da predestinação" são alvo de reflexão atenta, e quanto à "salvação", "não sendo senão hum puro favor de Deos", é apenas para os escolhidos ${ }^{32}$. O reconhecimento da importância do poder dos bispos nas suas dioceses e a defesa de uma total harmonia entre estes e o governo secular são ideias que perpassam nos textos de Caetano Brandão que Amaral transcreve e que apoia com contínuos comentários apologéticos. Estas são justamente ideias que fazem aproximar correntes jansenistas e regalistas. Que a jurisdição temporal que os Príncipes depositaram nas mãos do Clero ao longo dos séculos seja agora posta em causa pelos mesmos príncipes que a pretendem retomar, ciosos dos seus direitos, é coisa que não preocupa Fr. Caetano Brandão. Isso ajudará até à constituição de uma Igreja mais pura, mais próxima da sua origem primitiva. Em contraponto, ACA concorda vivamente e transcreve excertos de cartas do Bispo do Pará para o Ministro de Estado Martinho de Melo e Castro, onde esta articulação e boa harmonia entre os dois poderes (espiritual e temporal) são exemplares. ${ }^{33} \mathrm{O}$ que se traduz também, quase de forma paradigmática, nas

${ }^{30}$ J. S. da Silva Dias, Pombalismo e Teoria Política, Lisboa, Centro de História da Cultura da Universidade Nova de Lisboa, 1982, pp. 17-18.

${ }^{31}$ Braga, Typografia dos Órfãos, 1867 (primeira edição em 1818).

${ }^{32}$ Idem, cfr. Tomo I, pp. 401-402.

${ }^{33}$ Cfr., entre outras, págs. 85 e 86. Para estes temas, ver Evergton Sales Souza, Jansénisme et Réforme de l'Église dans l'Empire Portugais (1640 à 1790), Paris, Fundação Calouste Gulbenkian, 2004 e "Jansénisme et reforme de l'Église dans l'Amérique portugaise au XVIII ${ }^{e}$. siècle" in Revue de l' histoire des religions, Tomo 226-Fasc. 2, 2009, pp. 219-222; José Pedro Paiva, Os Bispos de Portugal e do Império (1495-1777), Coimbra, Imprensa da Universidade de Coimbra, 2006; Zília Osório de Castro, "O Regalismo em Portugal. António Pereira de Figueiredo", Cultura, História e Filosofia, VI (1987), p. 357-411 e "Jansenismo" in Carlos Moreira Azevedo, Dicio- 
viagens e visitas pastorais do antístite que se cruzam com a "Expedição dos Naturalistas" junto ao Amazonas, o bispo evangelizando ou tentando evangelizar os índios, os Naturalistas fazendo "as suas observações". Nem por isso deixa Caetano Brandão de fazer igualmente as suas observações, relata ACA, muito ricas e variadas, informando disso os seus correspondentes, entre os quais se encontrava também o Ministro de Estado dos assuntos ultramarinos. As suas informações, conselhos e avisos, disso tinha plena consciência, eram úteis à Igreja mas também ao Estado, governo central e local, pela sua utilidade política. Nesse sentido vão as suas observações sobre a condição dos Índios no Pará. Respeitando o Bispo as determinações do Directório dos Índios (criação do governo pombalino), que aprova, manifesta-se, no entanto, contra o facto destas não se cumprirem, o que acarreta graves prejuízos para os "gentios" em primeiro lugar, mas também efeitos muito nefastos tanto para a Igreja como para a Soberana. Nomeadamente na extrema diminuição de índios nas "Povoações do Estado", porque face às grandes dificuldades que experimentam e que Brandão expõe pormenorizadamente, os índios voltam para o mato. Poucos dias depois do regresso da visita pastoral, diz-nos ACA, já Caetano Brandão está a enviar uma "Representação a sua Magestade" para expor "as necessidades e misérias do seu Rebanho... que reclamam um efectivo remedio ... (e) que são negocio de tanto interesse para a gloria de Deus, e salvação de V. Magestade" ${ }^{34}$. Efectivamente, os negócios do império eram também uma questão de consciência ${ }^{35}$ e, para resolver os abusos, bastava que se cumprissem inviolavelmente as determinações régias do Directório.

Enfim, a Rainha e a Corte, diz ACA, tinham conhecimento dos exemplares procedimentos do Bispo do Pará, não houve pois hesitação em nomeá-lo, em 1789, para o Arcebispado de Braga. A notícia da nomeação, sumamente prestigiante, foi enviada pelo próprio ministro de Estado, Martinho de Melo. Foi

nário de História Religiosa de Portugal (direc.), Mem Martins, Círculo de Leitores, 2000-2001, vol. 3, p. 7-9. No final do séc. XVIII e no âmbito universitário coimbrão, os confrontos entre jansenismo e ultramontanismo continuavam: ver Cândido dos Santos, Jansenismo e Antijansenismo nos Finais do Antigo Regime, Porto, CITCEM/Edições Afrontamento, 2011, pp. 12-69.

${ }^{34}$ Idem, Tomo I, pp. 355-356.

${ }^{35}$ Para o estudo do peso da Teologia e do Direito na cultura política do Portugal imperial de um período anterior, ver Giuseppe Marcocci, A consciência de um império. Portugal e o seu mundo (secs. XV-XVII), Coimbra, Imprensa da Universidade, 2012. Sobre D. Maria I, refere ACA: "S. Ex. a [Caetano Brandão] me disse, que a primeira vez que beijára a mão à Rainha [aquando da sua nomeação], ponderando-lhe, que Sua Magestade ficava responsável diante de Deos da administração, para que o havia nomeado, Sua Magestade mostrando a comoção, que tal intimação fazia na sua delicada consciência, lhe segurou, que o havia ajudar em tudo o que della dependesse". 
também este que o recebeu em Lisboa, encaminhando-se ambos, de seguida, para o Palácio de Queluz, onde foram recebidos por D. Maria I.

A chegada de Caetano Brandão a Braga deixou antever de imediato, conta Amaral, a austeridade e rigor por que se pautaria a sua administração, pondo termo ao fausto que rodeava o bispo anterior (que além de bispo era príncipe). Não tardou por isso, em vários sectores, a contestação ao novo antístite. No entanto o "Povo", aqui como no Pará, manifestava exuberantemente o amor ao seu Bispo.

Segundo as palavras de Amaral, Caetano Brandão propunha-se por "modelos" os "Santos Bispos dos primitivos séculos" da Igreja. Por isso, para além de pedir por várias vezes ao seu amigo que movesse influências na Corte a favor das obras que se propõe levar a cabo, é também para apoiar o seu pensamento e acção em defesa de uma reforma da Igreja, que Caetano Brandão recorre à mestria de erudito e historiador de ACA. Logo no início do ano de 1793 Caetano Brandão escreve a Caetano do Amaral: "Ando meu amigo ... com forte sêde de dar á luz a Vida, e Obras do grande S. Martinho de Dume"36, era S. Martinho seu predecessor no arcebispado de Braga e ilustríssimo exemplo da Igreja primitiva, que tanto admirava. Como autor de tal livro, não via outro possível senão ACA: "Também aqui em Braga acharia muitos, que gostosamente aceitariam a incumbência, e já estive para a dar a alguns, se não fosse o receio que tenho de que ou a paixão pelas cousas de Braga, ou a falta de exactidão, e pureza diminua o valor da Obra ... Ora rogo-lhe, que tome á sua conta este negocio; ...poderá fazer alguns esclarecimentos lindíssimos, e muito próprios para avivar no espírito do Clero as preciosas lembranças da antiga Disciplina" ${ }^{37}$. Não admite pois qualquer recusa, esperançado em que o livro seja um contributo, juntamente com as suas próprias ordens e instruções, para uma feliz "revolução nos costumes", particularmente do Clero bracarense. Esta erudição e nostalgia pela Antiguidade cristã não é uma empresa desinteressada, trata-se de justificar a doutrina do presente pelo testemunho do antigo. Assim, para Caetano Brandão, este deveria ser um livro claramente empenhado em mostrar as vantagens da antiga Disciplina, "carregando a mão na pintura da beleza della". Sobre a forma e apresentação do texto, aconselha Caetano Brandão a António Caetano do Amaral que ela seja "á maneira de Tillemont" e Tillemont é, não o esqueçamos, um dos grandes eruditos pertencentes ao grupo de Port-Royal, centro de erudição crítica e de espiritualidade pro-

\footnotetext{
${ }^{36}$ Idem, Tomo II, p. 155.

${ }^{37}$ Idem, Tomo II, p. 156.
} 
-jansenista ${ }^{38}$. ACA trabalha com empenho e vigor, dando conta do andamento dos trabalhos ao seu amigo, este não se contém que não exclame: "bellissimo methodo! E então que erudição, e que critica!" 39 .

A esta obra vai juntar-se ainda outra, a Vida e Regras Religiosas de $S$. Fructuoso Bracarense ${ }^{40}$, que parte da iniciativa de Amaral mas que é também muito bem aceite por Caetano Brandão (a obra impressa apresenta-se como de sua encomenda). Das intuições certeiras e originalidade de Amaral neste livro sobre S. Frutuoso dão conta as investigações mais recentes: "a originalidade das suas propostas não mereceram o destaque que o seu valor faria supor" ${ }^{41}$. Logo na Introdução é o próprio autor, ACA, que articula este trabalho com as suas Memorias (Memoria III, para onde remete sempre que necessário) realizadas no âmbito da Academia das Ciências, bem como com o trabalho anterior sobre S. Martinho de Dume, dizendo: " servirá também como de suplemento a outro Opusculo, em que descrevemos o estado do nosso Terreno nesta epoca, em que foi dominado dos Visigodos, pelo que pertence ás Leis, Costumes, e Religião, reservando para lugar mais próprio o que dizia respeito á Disciplina das Igrejas" ${ }^{42}$. Caetano do Amaral integra, portanto, todas as partes da sua obra num todo, que ele não só entende como um todo mas que propõe ao leitor como um todo. Estudar o passado converte-se num meio de desenhar um futuro e, desse modo, de fixar um fim às acções e decisões do presente, seja para a Igreja ou para o Reino. Das suas convicções dá prova a própria tradução que faz destes textos antigos, ao traduzir, com alguma liberdade, por exemplo, a expressão original "humanae intelligentiae" por "Razão (repare-se na letra maiúscula) humana”, nos opúsculos de S. Martinho ${ }^{43}$.

Em Janeiro de 1819 morre António Caetano do Amaral, deixando por completar a obra que projectara mas na qual trabalhou até ao fim dos seus dias, dizendo o autor do seu elogio, recitado na Academia das Ciências, que "nenhuma outra distracção era capaz de o arrancar ao estudo, nenhuma outra ambição, a não ser a litteraria". Trabalho beneditino, de uma erudição paciente e exaustiva, até que "chegando a hum estado de magreza verdadeiramente

${ }^{38} \mathrm{Cfr}$. Bruno Neveu, Erudition et religion aux XVII ${ }^{e}$. et XVIII ${ }^{e}$. siècles, Paris, Albin Michel, 1994 e Chroniques de Port-Royal, número "Port-Royal et l' histoire”,1998

${ }^{39}$ Idem, Tomo II, p. 160.

${ }^{40}$ Ob. cit., 1805

${ }^{41}$ Paula Barata Dias, Os Textos Monásticos de Ambiente Frutuosiano, Viseu, Fundação Mariana Seixas, 2008, vol. I, p.150, nota 140.

${ }^{42}$ Vida, e Regras..., p. 1.

${ }^{43}$ Vida, e Opusculos..., ob. cit., p. 146. 
pasmoso, se viu em fim de todo privado de forças físicas" ${ }^{44}$. O mesmo nos diz Bruno Neveu de Tillemont: "Le regime de vie ascétique qu' observait Tillemont, s' ajoutant au labeur qu' il s'était imposé dans le champ des sciences ecclésiastiques, précipitèrent sa fin: il mourut épuisé." ${ }^{45}$

\section{Considerações finais}

António Caetano do Amaral, mergulhado nas fontes históricas, que estudou com método erudito e crítico, reflectiu, com elas e através delas, sobre os grandes e nevrálgicos problemas políticos do seu tempo. Tempo conturbado, tanto em Portugal como na Europa. Não esqueçamos que a sua vida e a sua obra correm, em boa parte, paralelamente com o eclodir e o desenrolar da Revolução Francesa (sobre a qual obtinha, sem dificuldade, notícias em Lisboa), teatro das mais desenfreadas paixões humanas. Governá-las era o que se impunha, estudá-las era o meio para tal e o contributo a que Amaral se propunha através da sua História Civil da Monarquia e também da sua História Eclesiástica. Estudou o passado português porque nele "verá o Legislador bem às claras o génio, e índole do seu Povo, as paixões que o tem dominado; os efeitos, que nelle tem produzido este, ou aquelle género de Legislação; e verá por consequência abrir-se-lhe diante dos passos a estrada, porque deve caminhar" ${ }^{46}$.

As modalidades de leitura e uso político da obra de Caetano do Amaral foram as mais variadas. O autor convocou várias e longínquas épocas, todas elas outras tantas formas de pensar o presente, pensou o autor o seu próprio presente, mas igualmente deu o passado e o presente a pensar a outros que o interpretaram e usaram de forma diferente (fossem eles liberais, conservadores ou outros).

\footnotetext{
${ }^{44}$ S. F. de Mendo Trigoso, ob. cit., pp. LIX e LXIII.

${ }^{45}$ Bruno Neveu, ob. cit., p. 95.

${ }^{46}$ Projecto de huma história civil..., ob. cit., p. 507.
} 